\title{
Social position, gender role, and treatment adherence among Colombian women living with HIV/AIDS: social determinants of health approach
}

\author{
Marcela Arrivillaga, ${ }^{1}$ Michael Ross, ${ }^{2}$ Bernardo Useche, ${ }^{3}$ \\ Martha Lucia Alzate, ${ }^{4}$ and Diego Correa ${ }^{1}$
}

Arrivillaga M, Ross M, Useche B, Alzate ML, Correa D. Social position, gender role, and treatment adherence among Colombian women living with HIV / AIDS: social determinants of health approach. Rev Panam Salud Publica. 2009;26(6):502-10.

ABSTRACT Objective. To assess and analyze the associations between adherence to treatment and social position in women living with HIV/AIDS.

Method. A cross-sectional, descriptive, correlational study among 269 Colombian women was conducted. Participants completed three questionnaires: a socio-demographic and clinical characteristics survey, a treatment adherence scale, and a social position survey.

Results. Women of low social position had a significantly higher probability of low treatment adherence $(O R=5.651, P<0.0001)$, and the majority of social position variables measured had a significant effect on adherence. A general model considering the variables "type of national health care plan" ("contributive," "subsidized," or, in the case of vinculadas or the uninsured, "none"); "having HIV-positive children"; and "level of viral load" was statistically reliable in predicting study participants' treatment adherence. Membership in the subsidized plan or being uninsured had a greater effect on the probability of low adherence than membership in the contributive plan $(O R=3.478, P<0.0001)$. Univariate regression analyses confirmed that women with HIV-positive children and a viral load $\geq 400$ copies/ml were more likely to have low adherence than women without those characteristics $(O R=2.395$, $P=0.0274$ and $O R=2.178, P=0.0050$, respectively).

Conclusions. Improving women's adherence to HIV/AIDS treatment in Colombia would require eliminating barriers to national health care system and comprehensive health care services and implementing programs that take into account women's role as maternal caregivers The findings underscore the need to integrate variables related to gender inequality and social position in treatment adherence analysis, as advocated in the social determinants of health approach.

Key words Patient compliance; HIV; AIDS; gender identity; Colombia.

1 Department of Social Sciences, Pontificia Universidad Javeriana, Cali, Colombia. Send correspondence and reprint requests to: Marcela Arrivillaga, Investigadora, Departamento de Ciencias Sociales, Pontificia Universidad Javeriana-Cali, Calle 18 No. 118-250, Cali,Valle del Cauca, Colombia; telephone: +57-2 321-8200; fax: +57-2 555-2550; e-mail: marceq@javerianacali.edu.co

2 Center for Health Promotion and Prevention Research, School of Public Health, University of Texas, Houston, Texas, United States of America.
The relationship between socio-economic-political factors and health outcomes has been recognized since the beginning of the history of public health

\footnotetext{
School of Public Health, University of Texas, Houston, Texas, United States of America.

4 School of Nursing, Universidad Nacional de Colombia, Bogotá, Colombia.
}

(1-5). In Latin America, conceptual models studying the link between macro socioeconomic structures and growing health inequities have been used in social medicine and public health since the 1970s (5).

It is also well established that the most valuable resources of a society-finan- 
cial benefits, and the mechanisms of social control-are unequally distributed or assigned, not only among different social positions but also by gender. This social and gender differentiation results in institutionalized imbalances between men and women in access to and control of resources $(6,7)$, and produces important differences in health outcomes (8). In Latin American countries, policies based on gender norms restrict women's access to productive resources such as land, income, education, technology, and credit. For example, in Colombia, it is estimated that housing ownership is $15 \%$ higher for men; unemployment is $6.8 \%$ higher in women; $52 \%$ of married women do not have a personal income; $38 \%$ of employed women work in the most precarious informal sector; $30 \%$ of households are headed by a woman, and $65 \%$ of those households are families living in conditions of poverty (9-10).

Colombia has the third-highest number of HIV / AIDS cases in Latin America. The country's level of incidence has shown a linear trend since 1983 and currently falls between $0.6 \%$ and $0.7 \%$ in women 15-49 years old $(11,12)$. However, it is estimated that for every case registered in the national HIV / AIDS epidemiological surveillance system there are about seven non-registered cases. Heterosexual transmission of HIV is the main mode of transmission among Colombian women, with $72 \%$ of cases detected in women attending vertical transmission prevention programs who report stable relationships with husbands or partners $(13,14)$.

Within this context, the current model for health care services in Colombia was established in 1993 by Law 100 and ratified in 2007 by Law 1122. Law 100 also established a two-tier system of national health care coverage-contributive and subsidized-provided through the General System of Social Security in Health (Sistema General de Seguridad Social en Salud, SGSSS). Those enrolled in the Contributive Mandatory Health Plan (Plan Obligatorio de Salud Contributivo, POS-C), which includes all individuals who are formally employed or earning more than twice the minimum wage, pay monthly dues for their health care coverage. Those enrolled in the Subsidized Mandatory Health Plan (Plan Obligatorio de Salud Subsidiado, POS-S), which includes government-defined subsidy-eligible individuals (those unable to pay the total amount of the insurance premium), receive restricted benefits (about half of those provided under the POS-C) subsidized by the government. This segment of the population obtains health care subsidies once they are registered with the System for Identification of Government Subsidies Recipients (SISBEN). Left out of this two-part system is a third category of Colombians known as vinculados or the uninsured. In spite of being below the poverty line, and due to the policies of the SISBEN, vinculados have not yet achieved access to the national health care system or the supply-driven resources originally targeted toward this population. Consequently, about 10 million citizens (approximately 25\% of the Colombian population) do not have any type of health care coverage (15) and must rely on health care services provided by local governments (primary care interventions, high-level or emergency services, and some intermediatelevel services), which often entail extremely high out-of-pocket expenses.

In the SGSSS, HIV/AIDS is considered a high-cost condition and is therefore not covered for approximately $66 \%$ of seropositive men and women, effectively blocking their access to antiretroviral therapy (ART). Data by gender on seropositives without access to ART are not available. Because access to ART and other types of health care is underprovided, non-continuous, deficient, and inadequate for the uninsured poor population, many people living with HIV/AIDS use a legal mechanism called a tutela (a writ for the protection of constitutional rights) to gain access to treatment $(13,16)$. However, activating this mechanism requires engaging in multiple bureaucratic procedures, resulting in delayed access to services, stress for patients and their families, and risk of worsening condition. Because Colombia's current health system is market-based, unemployed women and those working in the informal sector experience extremely limited access to health care services. Because most of this population is uninsured, any health services they do receive require extensive, often unaffordable out-of-pocket payments. Barriers to health care for these women are further exacerbated in the event of widowhood, partner abandonment, marital separation, or partner unemployment (7).

In the case of HIV/AIDS, access to health care resources is based on level of economic resources, gender, and social position. Therefore, the population most affected by barriers to care and treatment is largely composed of poor women, whose limited ability to pay for services, status as women, and low social position block their access to health care $(17,18)$. This, in turn, diminishes their ability to obtain and sustain treatment (19). In addition, poor women with HIV/AIDS face other challenges, such as unemployment or informal employment (working in the informal job sector); low income; low education; and inadequate nutrition and housing conditions-all of which imply difficulties in obtaining sufficient resources to enable them to follow any kind of ART satisfactorily (20).

Traditionally, adherence to treatment has been studied using both a biomedical and a psychosocial approach, based on analysis of general categories of variables related to the patient (e.g., age, education level, and coping mechanisms); health care personnel (e.g., quality of health care and communication skills); the illness or condition (e.g., state of the immune system); treatment (e.g., side effects); and health care systems (e.g., quality of health care and geographical barriers) (21-25). Several studies have shown that compared to male samples women with HIV / AIDS face major treatment adherence barriers, including delays in medical attention, non-use of ART, lack of financial support, poor quality of health care, and problems related to the doctor-patient relationship $(26,27)$. These problems are intensified among women living in rural areas (28). It has been suggested that certain aspects of the larger social context influence treatment adherence (29), including factors such as poverty; social/gender inequality; war; violence; cost of medication; CD4 count ${ }^{5}$ and viral load; cost of transportation; cost of missing days from work; cost of food and safe water; and costs associated with the inevitable changes in lifestyle resulting from HIV infection. Along with the direct effects of gender inequality on women's health care, it is important to analyze the indirect effects of gender on treatment adherence, such as women's limited access to the economic resources that determine their social position.

\footnotetext{
Number of CD4+ T-lymphocyte cells per $\mathrm{mm}^{3}$ of blood (measure used to analyze prognosis of HIVinfected individuals).
} 
To complement current biomedical and psychosocial approaches to the study of treatment adherence, and broaden the social perspective toward the issue, the current study aimed to: 1) assess and analyze the associations between treatment adherence and social position, and 2) identify and examine the association between treatment adherence and specific social position and socio-demographic/clinical variables in Colombian women living with HIV/ AIDS. These objectives emerged after a review of available data revealed a lack of consistency regarding the association between socioeconomic status and treatment adherence. The need for this type of study was further underscored when a more recent, systematic review including 116 studies concluded that there is no statistically significant association between socioeconomic status and adherence to HIV / AIDS treatment (30). At the same time, the lack of existing data on this topic eliminated the possibility of formulating directional hypotheses.

For the purposes of this study, social position was defined according to the criteria of the social determinants of health approach. This approach defines social position in terms of the variables that collectively determine a woman's "place" in society as well as the place where she actually lives, including area of residence; socioeconomic status; education; type of health care coverage (including "none"); job or livelihood; income level; and access to economic resources such as credit and property $(3,5,31)$. Therefore, this study focused on the above-mentioned variables, taking into account specific effects of gender, to assess the treatment adherence of Colombian women.

\section{METHOD}

This study is part of the Social Perspective of Adherence to Treatment in Colombian Women with HIV/AIDS macro project, which consists of two sequential studies (quantitative and qualitative) conducted between 2006 and 2008. This report analyzes the quantitative data, using a cross-sectional, descriptive, correlational design.

\section{Participants and procedures}

Participants included 269 women diagnosed with HIV / AIDS in five Colombian cities. Due to the nature of the sam- ple pool, which comprised a hidden and hard-to-reach segment of the population (female seropositives), along with data inconsistencies and incomplete records at the participating health centers, a convenience sample was used. Inclusive criteria included being under medical control in a health care center, being diagnosed more than six months prior to the study, having more than three months of treatment, being older than 18 years, and not being pregnant. The main exclusion criterion was documentation of a mental disorder diagnosis in the clinical history. Out of the 280 women initially contacted, $11(4 \%)$ refused to participate in the study for fear their names would be revealed (despite guarantees of confidentiality).

Women were recruited over an 11month period from HIV / AIDS programs at health care centers and nongovernmental organizations (NGOs) for people living with HIV/AIDS. Infection with HIV was confirmed with a Western blot test. Three questionnaires were applied to each study participant by appropriately trained personnel (except in the case of low educational level of the participant, which required administration of the surveys by the researchers, with the assistance of a support team). The research project was approved by the institutional review boards of the National University of Colombia (Universidad $\mathrm{Na}$ cional de Colombia, UN) and Javeriana University in Cali (Pontificia Universidad Javeriana Cali, PUJC). Written informed consent was obtained from all study participants.

\section{Measures}

Socio-demographic and clinical data survey. For the survey on socio-demographic and clinical characteristics, study participants provided data on area of residence, age, marital status, "family member(s) infected with HIV/AIDS," time of diagnosis, mechanism of HIV transmission, and most recent viral load and CD4 count.

Treatment adherence scale. The treatment adherence questionnaire included 21 items evaluating practices, motivations, beliefs, affect, barriers, and living conditions. Before its application, the content was validated with a pilot test and expert judges. The answer format followed a four-point Likert scale (with 1 representing "never" and 4 representing "always"). The variable was categorized on a scale of 21 to 84 , and "low" and "high" levels of adherence were established respectively as 21-61 points and 62-84 points. This classification was based on the overall mean of compliance in patients classified as "high adherence" in past studies, which ranged from $37 \%$ to $88 \%(32,33)$. "High adherence" in the current study was defined as complying with at least $64 \%$ of the treatment requirements (corresponding to a score of 62 or higher in the treatment adherence scale). Use of Cronbach's alpha test to assess the reliability of the scale resulted in a value of 0.812 (an alpha value $\geq 0.7$ indicates an acceptable level of scale reliability) (34). Table 1 presents the treatment adherence variables.

Social position survey. The social position survey included 16 items that evaluated eight characteristics of social position: residence; socioeconomic status; education; type of health care plan; job/ occupational profile, income; [women's] property holdings; and access to financial credit. The survey content was validated with a pilot test and expert judges. The variable was categorized on a scale of 7 to 21 , with levels of social position defined as "low" (7-11 points); "medium" (12-16 points); and "high" (17-21 points). This classification was made taking into account current Colombian criteria defining socioeconomic levels officially established in 1994 (35). The survey parameters for social position were also based on Breilh's criteria (36). Table 2 shows the variables included in the social position survey.

\section{Data analysis}

The statistical analyses included descriptive and analytic procedures. For descriptive purposes, the frequencies of responses to the items on the three survey instruments were examined first. For analytical purposes, univariate and multiple logistic regression models were estimated and odds ratios (OR) were used to characterize associations between the three groups of variables (social position, socio-demographic and clinical characteristics, and treatment adherence). The statistical programs SPSS version 14.0 (SPSS Inc., Chicago, Illinois, USA) and SAS version 9.0 (SAS Institute Inc., Cary, North Carolina, USA) were used. 
TABLE 1. Survey items for a questionnaire designed to determine treatment adherence in a crosssectional, descriptive, correlational study conducted among HIV-positive women in five Colombian cities, ${ }^{\text {a } 2006-2008}$

Compliance with medical appointments

Take medication as prescribed

Active research of information and education on HIV/AIDS and treatment

Direct communication for matters related to treatment with health care personnel

Handle side effects of antiretroviral therapy (ART)

Seek family support to comply with treatment

Seek social support to comply with treatment

Balance adherence with daily life routine and obligations

Resolution of health care system barriers to maintain treatment

Understand and accept diagnosis

Disruption of treatment due to emotional disorders attributed to HIV/AIDS

Role as family caregiver ("The care of my health can wait. Most important is the family care.")

Doubts about treatment benefits

Determination to continue treatment

Personal motivations contributing to treatment compliance

Perception that stigmatization by family and community interferes with treatment

Perception that stigmatization by health care workers interferes with treatment

Geographic barriers to accessing health care center

Economic problems interfering with treatment

Sufficient quality of nutrition and availability of proper diet to ensure adequate health

Difficulties in paying out-of pocket health care expenses for continuous treatment

${ }^{a}$ Cali and surrounding towns, Bogotá, Villavicencio, Pasto and surrounding towns, and Medellín.

\section{RESULTS}

\section{Socio-demographic and clinical characteristics}

The sample study was made up of 269 women diagnosed with HIV/AIDS and living in one of five cities in Colombia: Cali (including surrounding towns), Bogotá, Villavicencio, Pasto (including surrounding towns), and Medellín. Table 3 shows the socio-demographic and clinical characteristics of the study sample.

\section{Treatment adherence and social position}

Of the total sample, $43 \%$ of the women presented low adherence to treatment (vs. 57\% who obtained high levels of adherence), and $80 \%$ were classified as members of a low social position (vs. $20 \%$ classified as medium or high social position) (data not shown).

To assess the association between social position and treatment adherence, a univariate logistic regression model was constructed. As shown in Table 4, the estimated risk for low adherence was five times higher for the women in a low social position compared to those in a medium or high social position.
The univariate logistic regression analysis also indicated (with reliability or confidence intervals (CIs) of 95\%), that the majority of the variables in the social position survey had a significant effect on low adherence, including low socioeconomic status (regression coefficient $(b)=0.8093 ; P=0.0070 ; \mathrm{OR}=2.246$, CI = 1.248-4.044); educational level of high school or less $(b=1.0474$; $P=0.0003 ; \mathrm{OR}=2.850, \mathrm{CI}=1.625-5.000)$; enrollment in the SGSSS subsidized health care plan, or categorization as vinculada (uninsured) $(b=1.4212 ; P=$ $<0.0001 ; \mathrm{OR}=4.142, \mathrm{CI}=2.383-7.201)$; job/occupational profile A (e.g., factory worker, farm worker, or informal sector worker, such as a day laborer, street vender, short-order cook, maid, parking lot attendant, etc.) $(b=1.0182 ; P=$ 0.0030; $\mathrm{OR}=2.768, \mathrm{CI}=1.413-5.422)$; monthly income level of less than US \$200 $(b=0.7276 ; P=0.0133$; OR = $2.070, \mathrm{CI}=1.164-3.682)$; and lack of access to financial credit $(b=0.8885 ; P=$ 0.0194; OR = 2.431, CI = 1.155-5.120). It should be noted that for the property holdings variable, the "no property" response did not show a significant association with treatment adherence $(b=$ $0.6590 ; P=0.0782 ; \mathrm{OR}=1.933, \mathrm{CI}=$ $0.928-4.025)$.
To complement the analysis, multiple logistic regression was conducted to identify and examine which independent variables related to social position, socio-demographic, and clinical data were associated with treatment adherence. Through multiple correspondent analyses, the problem of multicollinearity was avoided, and the variable set was reduced. A general model made up of variables including type of health care plan, having HIV-positive children, and level of viral load was found to be statistically reliable to predict low or high adherence for the study participants $(-2 * \log -$ likelihood $=316.620$; chisquare (3) $=32.3803 ; P=<0.0001$ ). However, as shown in Table 5, the effect of the individual variables differed. For example, as noted in the table, enrollment in the subsidized health care plan or being uninsured had a greater effect on the likelihood of low adherence than enrollment in the contributive plan (reliability $99 \%$ ).

To verify the effects of the non-significant variables of the model obtained through multiple regression analysis, univariate regression analyses were conducted. Results of these tests indicated that the variables "having HIV-positive children" ( $b=0.8733 ; P=0.0274 ; \mathrm{OR}=$ 2.395, CI = 1.102-5.203) and "having a viral load $\geq 400$ copies $/ \mathrm{ml}^{\prime \prime}$ ( $b=0.7786$; $P=0.0050 ; \mathrm{OR}=2.178, \mathrm{CI}=1.266-3.750$ ) had a significant effect on low adherence. Social position, socio-demographic, and clinical variables that did not have a significant effect on adherence included "being a full-time housewife"; "being solely responsible for family income"; age; marital status; area of residence; having children; "living with children and partner," "living with children without a partner"; "having a partner with HIV/ AIDS"; "living with other family members or friends"; and time of diagnosis.

\section{DISCUSSION}

Adherence to treatment in HIV/AIDS cases is a key public health issue, especially with regard to women, who represent a vulnerable population. The main findings of the current study indicate 1) an association between treatment adherence and overall social position, and between treatment adherence and specific social position variables; 2) Colombian women with HIV / AIDS, especially those in a low social position, face seri- 
TABLE 2. Survey items for a questionnaire designed to determine level of social position in a cross-sectional, descriptive, correlational study conducted among HIV-positive women in five Colombian cities, ${ }^{\mathrm{a}}$ 2006-2008

\begin{tabular}{|c|c|}
\hline $\begin{array}{l}\text { Area of residence } \\
\text { Urban } \\
\text { Rural }\end{array}$ & $\begin{array}{l}\text { Type of national }\left(\text { SGSSS }^{b}\right) \text { health plan } \\
\text { Subsidizedc } \\
\text { Contributive }^{d}\end{array}$ \\
\hline $\begin{array}{l}\text { Socioeconomic status (level) } \\
1-2 \text { (low) }\end{array}$ & $\begin{array}{l}\text { Contributive plus PMPe } \\
\text { None }^{f}\end{array}$ \\
\hline $\begin{array}{l}3-4 \text { (medium) } \\
5-6 \text { (high) }\end{array}$ & $\begin{array}{l}\text { Type of health plan membership } \\
\text { Subscriber (enrollee) }\end{array}$ \\
\hline $\begin{array}{l}\text { Education (highest level reached) } \\
\text { Grammar school } \\
\text { High school } \\
\text { Trade school/college } \\
\text { Postgraduate }\end{array}$ & Beneficiary (dependent) \\
\hline \multicolumn{2}{|c|}{$\begin{array}{l}\text { Job/occupational profile } \\
\text { Profile A: Factory worker; farm worker; informal sector worker (e.g., day laborer, street vender, maid, } \\
\text { parking lot attendant, short-order cook, etc.) }\end{array}$} \\
\hline \multicolumn{2}{|c|}{$\begin{array}{l}\text { Profile B: Small business owner; low-level salesperson; service industry worker; low-level employee of } \\
\text { public or private company (e.g., secretary or clerk); self-employed professional with undergraduate degree. }\end{array}$} \\
\hline \multicolumn{2}{|c|}{$\begin{array}{l}\text { Profile C: Female business owner or manager of large company; upper-level employee of public or private } \\
\text { company; self-employed professional with postgraduate degree }\end{array}$} \\
\hline \multicolumn{2}{|l|}{ Full-time housewife } \\
\hline \multicolumn{2}{|l|}{ Unemployed } \\
\hline $\begin{array}{l}\text { Monthly income (level) } \\
<\text { US } \$ 200 \\
\text { US } \$ 200-\text { US } \$ 1000 \\
>\text { US } \$ 1000\end{array}$ & $\begin{array}{l}\text { Property holdings } \\
\text { None } \\
1 \text { property } \\
2 \text { or more properties }\end{array}$ \\
\hline $\begin{array}{l}\text { Solely responsible for family income } \\
\text { Yes } \\
\text { No }\end{array}$ & $\begin{array}{l}\text { Access to financial credit } \\
\text { None } \\
\leq \text { US } \$ 17000 \\
>\text { US } \$ 17000\end{array}$ \\
\hline
\end{tabular}

a Cali and surrounding towns, Bogotá, Villavicencio, Pasto and surrounding towns, and Medellín.

${ }^{b}$ General System of Social Security in Health (Sistema General de Seguridad Social en Salud, SGSSS).

c Subsidized Mandatory Health Plan (Plan Obligatorio de Salud Subsidiado, POS-S) for government-defined subsidy-eligible individuals (those unable to pay the total amount of the insurance premium) who are registered with the System for Identification of Government Subsidies Recipients (SISBEN)) and receive restricted benefits (about half of those provided under the POS-C) subsidized by the government.

${ }^{d}$ Contributive Mandatory Health Plan (Plan Obligatorio de Salud Contributivo, POS-C) for individuals who are formally employed or earning more than twice the minimum wage and pay monthly dues for health care coverage.

e Prepaid Medical Plans (Planes de Medicina Prepagada, PMP) (supplemental private health insurance).

${ }^{\dagger}$ In Colombia, those who are unable to pay any health insurance premiums, known as vinculados, remain uninsured and thus face barriers to medical care.

ous barriers to adherence imposed by the structure of the health system; and 3) women's role as caregivers for HIV-positive children is a gender condition that affects adherence to their own treatment requirements. The statistically significant associations found in the study underscore the importance of social determinants versus practices, motivations, beliefs, affect, and living conditions with regard to treatment adherence.

Other studies that have explored associations between socioeconomic status and HIV/AIDS treatment adherence have had inconsistent results. In general, socioeconomic aspects in these studies are measured and analyzed as independent factors. A majority of authors used the variable of income level as the indi- cator of social position. In contrast, this study considered social position as a group of characteristics acting together to define, in this case, seropositive women's place in Colombian society.

According to the current study results on specific barriers to treatment adherence, women living in poverty conditions have a high probability of health care and socioeconomic deficits such as limited access to ART, low income, inadequate diet and housing, and low levels of education, as well as extra out-ofpocket health expenses. Some authors (37) found that poor women with HIV/AIDS experience delayed diagnosis and had less access to health care compared to their male counterparts, which contributed to a bleak prognosis.
Although living in poverty and being female have been shown to be fundamental determinants of the dynamics of the HIV epidemic (17-20), research on adherence to treatment in this specific population is scarce. The results of this study concur with previous data on the relationship between poor economic situation and HIV/AIDS treatment adherence in male and female samples (29, 37-39). However, more research is required to confirm associations between treatment adherence and variables related to social position and gender role.

TABLE 3. Socio-demographic and clinical characteristics of HIV-infected women in a crosssectional, descriptive, correlational study conducted in five Colombian cities, ${ }^{\mathrm{a}}$ 2006-2008

\begin{tabular}{|c|c|c|}
\hline Characteristic & $\begin{array}{l}\text { No. HIV-infected } \\
\text { women }(n=269)\end{array}$ & $\%$ \\
\hline \multicolumn{3}{|l|}{ Area of residence } \\
\hline Urban & 243 & 90 \\
\hline Rural & 26 & 10 \\
\hline \multicolumn{3}{|l|}{ Age (years) } \\
\hline $18-25$ & 30 & 11 \\
\hline $26-40$ & 140 & 52 \\
\hline $41-59$ & 89 & 33 \\
\hline$\geq 60$ & 10 & 4 \\
\hline \multicolumn{3}{|l|}{ Marital status } \\
\hline \multicolumn{3}{|l|}{ Married/in common } \\
\hline Single & 59 & 22 \\
\hline Separated or divorced & 40 & 15 \\
\hline Widowed & 29 & 11 \\
\hline \multicolumn{3}{|l|}{ Has children } \\
\hline Yes & 161 & 60 \\
\hline No & 108 & 40 \\
\hline \multirow{2}{*}{\multicolumn{3}{|c|}{ Family member living with }} \\
\hline \multicolumn{2}{|l|}{ HIV/AIDS } & \\
\hline Partner & 136 & 51 \\
\hline Child & 51 & 19 \\
\hline \multicolumn{3}{|l|}{ Living with: } \\
\hline Children (without a partner) & 94 & 35 \\
\hline Children and partner & 99 & 37 \\
\hline \multicolumn{2}{|l|}{ Other family members } & 28 \\
\hline \multicolumn{3}{|l|}{ Source of HIV transmission } \\
\hline Sexual & 264 & 98 \\
\hline Blood transfusion & 3 & 2 \\
\hline \multicolumn{3}{|l|}{ Time of diagnosis } \\
\hline$>2$ years ago & 210 & 78 \\
\hline $1-2$ years ago & 42 & 16 \\
\hline$<1$ year ago & 17 & 6 \\
\hline \multicolumn{3}{|l|}{ Viral load } \\
\hline$<400$ copies $/ \mathrm{ml}$ & 169 & 63 \\
\hline$\geq 400$ copies $/ \mathrm{ml}$ & 99 & 37 \\
\hline \multicolumn{3}{|l|}{ CD4 count ${ }^{\mathrm{b}}$} \\
\hline$<200$ cells $/ \mathrm{ml}$ & 51 & 19 \\
\hline $200-300$ cells $/ \mathrm{ml}$ & 112 & 42 \\
\hline$>300$ cells $/ \mathrm{ml}$ & 105 & 39 \\
\hline
\end{tabular}

a Cali and surrounding towns, Bogotá, Villavicencio, Pasto and surrounding towns, and Medellín.

${ }^{b}$ Number of CD4+ T-lymphocyte cells per $\mathrm{mm}^{3}$ of blood (measure used to analyze prognosis of HIV-infected individuals). 
TABLE 4. Univariate logistic regression analysis of the association between low treatment adherence and low social position (versus medium and high social position) in a cross-sectional, descriptive, correlational study conducted among 269 HIV-positive women in five Colombian cities, ${ }^{\text {a } 2006-2008}$

\begin{tabular}{lccccc}
\hline & $\begin{array}{c}\text { Regression } \\
\text { coefficient }(b)\end{array}$ & $\begin{array}{c}\text { Wald test } \\
\text { statistic }\end{array}$ & DF & $P$-value & $\begin{array}{c}\text { Odds ratio } \\
\left(95 \% \mathrm{Cl}^{\mathrm{c}}\right)\end{array}$ \\
\hline Constant $\left(b_{0}\right)$ & -1.7427 & 18.0960 & 1 & $<0.0001$ & $\mathrm{NA}^{\mathrm{d}}$ \\
Low social position $\left(b_{1}\right)$ & 1.7319 & 15.8323 & 1 & $<0.0001$ & $5.651(2.408-13.262)$ \\
\hline
\end{tabular}

${ }^{a}$ Cali and surrounding towns, Bogotá, Villavicencio, Pasto and surrounding towns, and Medellín.

${ }^{b} \mathrm{DF}=$ degrees of freedom.

${ }^{c} \mathrm{Cl}=$ confidence interval.

d $\mathrm{NA}=$ not applicable.

TABLE 5. Multivariate logistic regression analysis of social position and socio-demographic/clinical characteristics associated with treatment adherence among HIV-positive women $(n=269)$ in a cross-sectional, descriptive, correlational study conducted in five Colombian cities, ${ }^{a}$ 2006-2008

\begin{tabular}{lcccccr}
\hline & $\begin{array}{c}\text { Regression } \\
\text { coefficient }\end{array}$ & $\begin{array}{c}\text { Wald test } \\
\text { statistic }\end{array}$ & DFb & $\begin{array}{c}\text { Odds } \\
\text { ratio }\end{array}$ & $\begin{array}{c}95 \% \mathrm{Cl}^{\mathrm{c}} \\
\text { (range) }\end{array}$ & $P$-value \\
\hline $\begin{array}{l}\text { Constant } \\
\begin{array}{l}\text { Member of subsidized } \\
\quad \text { national health care plan, }\end{array}\end{array}$ & -1.1936 & 27.6470 & 1 & NA $^{\mathrm{d}}$ & $\mathrm{NA}$ & $<0.0001$ \\
$\quad$ or vinculada (uninsured) & 1.2465 & 18.0501 & 1 & 3.478 & $1.957-6.181$ & $<0.0001$ \\
Has children with HIV/AIDS & 0.7317 & 2.9675 & 1 & 2.079 & $0.904-4.779$ & 0.0850 \\
Viral load $\geq 400$ copies/ml & 0.5128 & 2.8939 & 1 & 1.670 & $0.925-3.015$ & 0.0889 \\
\hline
\end{tabular}

a Cali and surrounding towns, Bogotá, Villavicencio, Pasto and surrounding towns, and Medellín.

${ }^{b} \mathrm{DF}=$ degrees of freedom.

${ }^{\mathrm{C}} \mathrm{Cl}=$ confidence interval.

d $\mathrm{NA}=$ not applicable.

Another significant finding of the study was that one of the main barriers to treatment adherence for poor women in Colombia with HIV / AIDS was being uninsured, or enrollment in the subsidized national health plan. Women enrolled in the subsidized plan generally receive care through POS-S Administrator Agencies (Empresas Promotoras de Salud del Régimen Subsidiado), which provide limited benefits. This finding may help explain the low health care quality and patient satisfaction reported by other researchers $(28,40)$. According to the authors of the current study, this treatment adherence barrier is an indirect consequence of less-than-equal access to timely and continuous care by women of low social position in Colombia, stemming from the flawed structure of the current national health system.

This study confirms that in the case of poor women with HIV/AIDS there is a systematic non-fulfillment of the commitments made by the Colombian government related to the right to universal and equitable access to health care (41). Access to the national health system for the Colombian population depends on either the capacity to afford it or the ability to meet the eligibility criteria for SISBEN subsidies $(42,43)$. In terms of insurance deficits, the continued prevalence of economic and gender discrimination leaves women more negatively affected than the majority of male enrollees $(43,44)$. Specifically, women in a lower social position receive insufficient health services, have higher out-of-pocket health care costs, and, as this study shows, a higher probability of less adherence to HIV/AIDS treatment, resulting in a much greater risk of mortality from AIDS. Most adherence problems among seropositive women enrolled in the subsidized plan stem from the restricted access to health services that characterizes this plan. Many vinculados remain on long waiting lists for access to treatment in public hospitals and thus experience serious problems related to access and quality of care. In addition, these uninsured individuals have no chance of participating in the few existing HIV/AIDS integral treatment programs. These barriers to access often force women to take legal action against the national health system in order to maintain access to HIV/AIDS treatment.
In other words, the Colombian national health care system does not provide gender-equitable access to its services (access based on need, regardless of gender or social position).

In addition to the above, a main finding of this study involves the effect of having HIV-positive children on adherence among maternal caregivers. Some authors have shown that women with HIV/ AIDS face different, specific stresses and are often overburdened with family care responsibilities at the expense of their own health (45-47). Women facing the double challenge of being patients and homemakers frequently must handle family-related difficulties that interfere with their treatment adherence. Some authors have observed that traditional models of medical care do not sufficiently address the specific needs of these women. For example, according to previous studies, when women receive help from others in the area of childcare their adherence to medical appointments improves significantly (26). According to predominant cultural norms in Colombia, women assume the main responsibility of taking care of their families. A diagnosis of 
HIV / AIDS in one or more of their children constitutes an additional burden for mothers who are themselves infected. This situation is especially onerous for women living without a partner. In the current study, it was observed that women with HIV / AIDS were more worried about and devoted more attention to their children's treatment than their own. They kept medical appointments, complied with prevention practices, ensured their children received the prescribed schedule of ART, and, with the same level of diligence, pursued legal actions to try to guarantee continued access to it.

\section{Conclusions}

The main findings of this study provide evidence of statistical associations between social position and HIV/AIDS treatment adherence. They also demonstrate associations between adherence and the socio-demographic variables "type of health care plan" and "having HIV-positive children." However, the authors conclude that the concepts of gender role and social position were not wholly integrated in their analyses of treatment adherence among seropositive women. Therefore, additional studies based on social determinants of health are needed to confirm these associations. Advocating a perspective beyond that of traditional biomedical and psychosocial approaches, in future research, the authors of this study recommend HIV/ AIDS treatment adherence be defined as "complex behavior promoting adaptation, psychological adjustment, appropriate health care, and quality of life during the HIV/AIDS infection process, determined by way of life, social position, and the health care system." Relevant variables related to "way of life" include patient practices, motivations, beliefs, and affect as well as any living conditions affecting adherence. This definition is based on a conceptual model devised by Breilh (5) that offers a theoretical, episte- mological, and praxiological framework for analyzing social processes related to individual health. Combined with the application of a social stratification model (4), the use of this framework can help generate viable mechanisms for carrying out political actions promoting the health, quality of life, and treatment adherence of people living with HIV / AIDS.

Carrying out structural interventions in Colombia to promote gender equality and related improvements in health outcomes for women requires the design and implementation of more and better public policies to promote equitable income for woman, facilitate their access to credit, and provide them with the right to work in order to increase their well-being and economic independence. This, in turn, requires consideration of women's role as maternal caretakers as well as other gender-related issues directly or indirectly affecting women's health. Another prerequisite for achieving progress in this area is a rights-based health system based on the principles of equity and universality. It is inconceivable that the risk of low adherence for a poor, uninsured woman (vinculada) with HIV/AIDS is five times that of a woman with a medium or high social position, and three times that of a woman enrolled in the national subsidized health care plan. This level of disparity calls for structural change in the health system as soon as possible. In the meantime, the Colombian government must at least guarantee access to timely and continuous ART. In terms of care, the authors recommend comprehensive gender-focused programs, under state control and supervision, that include childcare; psychological and family social services intervention; gynecological/specialized care; and support in HIV / AIDS education, and nutrition. It is reasonable to argue that attention to basic needs can be more beneficial than direct attention to adherence, particularly in the case of women with a low social position. Better education and training among health care providers on the impact of social position and gender on adherence among people living with $\mathrm{HIV} / \mathrm{AIDS}$ is also needed.

Finally, through future research on treatment adherence and its association with social position, socio-demographic, and clinical variables, the authors recommend further validation of the hypothesis presented in this report. Comparative studies should be carried out between male and female samples to identify links between these variables and thus improve the characterization of gender differences. Other studies on structural barriers of health systems and their association with gender-role variables would also contribute to a more integrated approach to analysis of treatment adherence. Lastly, to address the limitations in the scope of the current study's sample population in terms of social position, explained above, the authors recommend the inclusion of a wider proportion of women with medium and high social position. While the current study experienced difficulty in locating seropositives with a high social position (because they tended to hide their condition and did not appear on health institutions' registers or attend NGO support groups), this population could be studied further through the use of a different research approach, such as the use of special quantitative research sampling methods, or qualitative data collection.

Acknowledgments. This study was conducted with funding from Javeriana University (Pontificia Universidad Javeriana) in Cali. The authors also acknowledge the contributions to the study's data collection and literature review by Paula Andrea Hoyos, research assistant for the Health and Quality of Life Research Group, a category A research group recognized by the Administrative Department for Science, Technology and Innovation (COLCIENCIAS), a Colombian government agency.

\section{REFERENCES}

1. Rosen G. From medical police to social medicine: essays on the history of health care. New York: Science History Publications; 1974.

2. Krieger N. Theories for social epidemiology in the 21st century: an ecosocial perspective. Int J Epidemiol. 2001;30(4):668-77.
3. Lynch J, Kaplan G. Socioeconomic position. In: Berkman LF, Kawachi I, editors. Social epidemiology. 1st ed. Oxford: Oxford University Press; 2000. p. 13-35.

4. Diderichsen F, Evans T, Whitehead M. The social basis of disparities in health. In: Evans T, Whitehead M, Diderichsen F,
Bhuiya A, Wirth E, editors. Challenging inequities in health: from ethics to action. New York: Oxford University Press; 2001. p. 13-23.

5. Breilh J. Epidemiología crítica. Ciencia emancipadora e interculturalidad. Buenos Aires: Lugar Editorial; 2003. 
6. Breilh J. El género entre fuegos de inequidad y esperanza. In: Siu Bermúdez I, Dierckxsens W, Guzmán L, editors. Antología latinoamericana y del Caribe: mujer y género. Periodo 80-90. Managua: Universidad Centroamericana; 1999.

7. Gómez Gómez E. Género, equidad y acceso a los servicios de salud: una aproximación empírica. Rev Panam Salud Publica. 2002;11(56):327-34.

8. Kunst AE, Bos V, Lahelma E, Bartley M, Lissau I, Regidor E, et al. Trends in socioeconomic inequalities in self-assessed health in 10 European countries. Int J Epidemiol. 2005;34(2):295-305

9. Economic Commission for Latin America and the Caribbean. Social panorama of Latin America 2006. Santiago: United Nations; 2006 [cited 2008 Mar 20]. Available from: http:// www.eclac.cl/publicaciones/xml/4/27484/ PSI2006_FullText.pdf.

10. Departamento Administrativo Nacional de Estadística (CO). Mercado laboral por sexo. Gran Encuesta Integrada de Hogares. Bogotá: DANE; 2008

11. Prieto F, Osorio A, De Neira M; Grupo de Vigilancia Centinela de VIH. Prevalencia del VIH en población general de Colombia 2003: VI Estudio Nacional Centinela de VIH 20032004. Primera Fase. Inf Quinc Epidemiol Nac (Colombia). 2004;9(23-24):362-76.

12. Garcia R, Prieto F, Rincon J, Arenas C, Caicedo S, Rey G. Reducción de la transmisión madre hijo del VIH en Colombia: dos años de experiencia nacional, 2003-2005. Biomédica. 2005;25(4):547-64.

13. García R, Luque R, McDouall J, Moreno LA. Infección por VIH/SIDA en Colombia: estado del arte 2000-2005. Bogotá: Programa Conjunto de las Naciones Unidas sobre el VIH/ SIDA, Ministerio de la Protección Social de Colombia; 2006

14. World Health Organization; Joint United Nations Programme on HIV/AIDS; United Nations Children's Fund. Epidemiological fact sheet on HIV and AIDS. Core data on epidemiology and response. Colombia 2008 update. Geneva: UNAIDS/WHO Working Group on Global HIV/AIDS and STI Surveillance; 2008

15. Vega R, Jara MI. Década de los noventa: discurso de la focalización de subsidios de salud. Rev Gerenc Políticas Salud. 2002;1(2):82-112.

16. Abadia CE, Oviedo DG. Bureaucratic itineraries in Colombia. A theoretical and methodological tool to assess managed-care health care systems. Soc Sci Med. 2009;68(6): $1153-60$.

17. Farmer P. Women, poverty, and AIDS. In: Farmer P, Connors M, Simmons J, editors. Women, poverty, and AIDS: sex, drugs, and structural violence. Monroe (ME): Common Courage Press; 1996. p. 3-38.

18. Poundstone KE, Strathdee SA, Celentano DD. The social epidemiology of human immunodeficiency virus/acquired immunodeficiency syndrome. Epidemiol Rev. 2004;26(1): 22-35.
19. International Community of Women Living with HIV/AIDS. La visión de ICW 3: mujeres seropositivas, pobreza y desigualdad de género. London: ICW; 2004 [cited 2005 Sep 10]. Available from: www.icwlatina.org/ imagenes/biblioteca/cuad.3.pdf.

20. Stillwaggon E. Reducing environmental risk to prevent HIV transmission in Sub-Saharan Africa. Africa Policy J. 2006;1:36-56.

21. Chesney MA. Factors affecting adherence to antiretroviral therapy. Clin Infect Dis. 2000;30 Suppl 2:S171-6.

22. Turner-Cobb I, Gore-Felton C, Maroua F, Koopman C, Kim P, Israelski D, et al. Coping, social support, and attachment style as psychosocial correlates of adjustment in men and women with HIV/AIDS. J Behav Med. 2002;25(4):337-53.

23. Burke-Miller JK, Cook JA, Cohen MH, Hessol NA, Wilson TE, Richardson JL, et al. Longitudinal relationships between use of highly active antiretroviral therapy and satisfaction with care among women living with HIV/AIDS. Am J Public Health. 2006;96(6): 1044-51. Epub 2006 May 2.

24. Arrivillaga M, Correa D, Varela MT, Holguín LE, Tovar JR. Variables psicológicas en mujeres diagnosticadas con VIH/SIDA: un estudio correlacional. Univ Psychol. 2006;5(3): 659-67.

25. Correa D, Salazar IC, Arrivillaga M. Impacto emocional e intervención psicológica con personas diagnosticadas con VIH/SIDA. In: Arrivillaga M, Correa D, Salazar IC, editors. Psicología de la salud: abordaje integral de la enfermedad crónica. Bogotá: Manual Moderno; 2007. p. 27-50.

26. Roberts KJ, Mann T. Barriers to antiretroviral medication adherence in HIV-infected women. AIDS Care. 2000;12(4):377-86.

27. Ickovics JR, Meade CS. Adherence to HAART among patients with HIV: breakthroughs and barriers. AIDS Care. 2002;14(3):309-18.

28. Jia H, Uphold C, Wu S, Reid K, Findley K, Duncan P. Health-related quality of life among men with HIV infection: effects of social support, coping, and depression. AIDS Patient Care STDS. 2004;18(10):594-603.

29. Castro A. Adherence to antiretroviral therapy: merging the clinical and social course of AIDS. PLoS Med. 2005;2(12):e338. Epub 2005 Oct 4.

30. Falagas ME, Zarkadoulia EA, Pliatsika PA, Panos G. Socioeconomic status (SES) as a determinant of adherence to treatment in HIV infected patients: a systematic review of the literature. Retrovirology. 2008;5(1):13. doi: 10.1186/1742-4690-5-13.

31. Evans $T$, Whitehead M, Diderichsen F, Bhuiya A, Wirth M, editors. Challenging inequities in health: from ethics to action. New York: Oxford University Press; 2001.

32. Stein MD, Rich JD, Maksad J, Chen $\mathrm{MH}, \mathrm{Hu}$ $\mathrm{P}$, Sobota $\mathrm{M}$, et al. Adherence to antiretroviral therapy among HIV-infected methadone patients: effect of ongoing illicit drug use. Am J Drug Alcohol Abuse. 2000;26(2): 195-205.
33. DiMatteo MR. Variations in patients' adherence to medical recommendations: a quantitative review of 50 years of research. Med Care. 2004;42(3):200-9.

34. Nunnally JC, Bernstein IH. Psychometric theory. 3rd ed. New York: McGraw-Hill; 1994.

35. Departamento Administrativo Nacional de Estadística (CO). Estratificación socioeconómica. Versión mayo 2004. Manual metodológico No. 1. Información para alcaldes y autoridades de los municipios y distritos. Bogotá: DANE; 2004.

36. Breilh J. Breve recopilación sobre operacionalización de la clase social para encuestas en la investigación social. Quito: Centro de Estudios y Asesoría en Salud; 2003.

37. Daily J, Farmer P, Rhatigan J, Katz J, Furin J. Women and HIV infection: a different disease? In: Farmer P, Connors M, Simmons J, editors. Women, poverty, and AIDS: sex, drugs and structural violence. Monroe (ME): Common Courage Press; 1996. p. 125-44.

38. Carballo E, Cadarso-Suárez C, Carrera I, Fraga J, de la Fuente J, Ocampo A, et al. Assessing relationships between health-related quality of life and adherence to antiretroviral therapy. Qual Life Res. 2004;13(3):587-99.

39. Glass TR, De Geest S, Weber R, Vernazza PL, Rickenbach M, Furrer H, et al. Correlates of self-reported nonadherence to antiretroviral therapy in HIV-infected patients: the Swiss HIV Cohort Study. J Acquir Immune Defic Syndr. 2006;41(3):385-92.

40. Bell EJ. Advocacy training by the International Community of Women Living with HIV/AIDS. Gend Dev. 2005;13(3):70-9.

41. Arbeláez M. Evaluación de la eficacia del derecho a la salud en Colombia a partir del proceso de descentralización sanitaria. Derecho y Salud. 2007;15(1):29-74

42. Corte Constitucional de Colombia, Sala Segunda de Revision, Sentencia T-760 [Colombian Official Document]. July 31, 2008.

43. Echeverri E. La salud en Colombia: abriendo el siglo ... y la brecha de las inequidades. Rev Gerenc Políticas Salud. 2002;1(3):76-94.

44. Franco S. Para que la salud sea pública: algunas lecciones de la reforma de la seguridad social en Colombia. Rev Gerenc Políticas Salud. 2003;2(4):58-69.

45. Gurung R, Taylor S, Kemeny M, Myers $H$. HIV is not my biggest problem: the impact of HIV and chronic burden on depression in women at risk for AIDS. J Soc Clin Psychol. 2004;23(4):490-511.

46. Hackl KL, Somlai AM, Kelly JA, Kalichman SC. Women living with HIV/AIDS: the dual challenge of being a patient and caregiver. Health Soc Work. 1997;22(1):53-62.

47. Hudson AL, Lee KA, Portillo CJ. Symptom experience and functional status among HIV-infected women. AIDS Care. 2003;15(4): 483-92.

Manuscript received on 21 October 2008. Revised version accepted for publication on 20 June 2009. 
RESUMEN Objetivo. Evaluar y analizar las asociaciones existentes entre la adhesión al tratamiento y la posición social de las mujeres con $\mathrm{VIH} /$ sida.

\section{Posición social, papel de género y adhesión al tratamiento en mujeres colombianas con VIH/sida: enfoque de los determinantes sociales de la salud}

Métodos. Se realizó un estudio transversal, descriptivo y correlacional con 269 colombianas. Las participantes respondieron tres cuestionarios: uno sobre las características sociodemográficas y clínicas, uno sobre su posición social y una escala sobre la adhesión al tratamiento.

Resultados. Las mujeres de baja posición social tenían una mayor probabilidad de presentar baja adhesión al tratamiento $(\mathrm{OR}=5,651 ; P<0,0001)$; la mayoría de las variables de posición social influyeron significativamente sobre la adhesión. Un modelo general con las variables "tipo de plan nacional de salud" ("contributivo", "subsidiado" o, en las vinculadas y las no aseguradas, "ninguno"), "tener hijos positivos al VIH" y "nivel de carga viral" resultó estadísticamente fiable para predecir la adhesión al tratamiento. Ser miembro del plan subsidiado o no tener seguro influyeron más en la probabilidad de baja adhesión al tratamiento que ser miembro del plan contributivo (OR =3,478; $P<0,0001)$. El análisis de regresión monofactorial confirmó que las mujeres con hijos positivos al VIH o carga viral $\geq 400$ copias $/ \mathrm{mL}$ tenían mayor probabilidad de presentar baja adhesión que las mujeres sin esas características ( $\mathrm{OR}=2,395 ; P=0,0274$ y $\mathrm{OR}=2,178 ; P=0,005$, respectivamente).

Conclusiones. Mejorar la adhesión de las mujeres al tratamiento para el VIH/sida en Colombia requiere eliminar barreras al sistema nacional de salud, brindar servicios integrales e implementar programas que tomen en cuenta el papel de las mujeres como madres cuidadoras de enfermos. Estos resultados subrayan la necesidad de integrar variables relacionadas con la inequidad de género y la posición social al análisis de la adhesión al tratamiento, como promueve el enfoque de determinantes sociales de la salud.

Palabras clave Cooperación del paciente; VIH; SIDA; identidad de género; Colombia. 